\title{
A frequent keratin 8 p.L227L polymorphism, but no point mutations in keratin 8 and 18 genes, in patients with various liver disorders
}

\author{
M Hesse, T Berg, B Wiedenmann, U Spengler, R P Woitas, T M Magin
}

J Med Genet 2004;41:e42 (http://www.jmedgenet.com/cgi/content/full/41/4/e42). doi: 10.1136/jmg.2003.012393

K eratins (K) 8 and 18 are the first intermediate filament proteins present in the early embryo, and form the backbone of the intermediate filament cytoskeleton in all simple internal epithelia. Mice with a combined deficiency in K8/K19 and K18/K19 suffer from midgestational lethality with full penetrance, which strongly supports an essential keratin function in extraembryonic epithelia. Moreover, mutations in $\mathrm{K} 8$ and $\mathrm{K} 18$ have been reported to present risk factors in liver disease of multiple aetiologies. This mutation analysis of the complete K8 and K18 genes, using DHPLC technology, involved screening blood samples from 256 patients diagnosed positive for various liver disorders, and from 100 individuals serving as controls. None of the previously reported mutations in $\mathrm{K} 8$ and $\mathrm{K} 18$ was found in any of the samples, nor was a positive correlation observed between K8 and K18 mutations to cryptogenic cirrhosis or to chronic liver disease of other origin. However, a novel polymorphism was detected in exon 4 of the $\mathrm{K} 8$ gene, leaving L227 unaltered, in both patient and control samples.

Type I and type II keratins belong to the large gene family coding for intermediate filament proteins. Among the 27 type I and 27 type II keratins known to exist in the human genome, type I K18 and type II K8 form copolymers and are coexpressed in all embryonic and internal epithelia. ${ }^{1}$ DNA linkage analysis and transgenic animal experiments have established that dominant acting point mutations in epidermal keratin genes lead to a large number of skin fragility syndromes, including epidermolysis bullosa simplex. The majority of these mutations are highly conserved with regard to their position. ${ }^{2}$ The molecular mechanism leading to cell fragility is not well understood, but it is clear that an intact cytoskeleton is required for epithelial homeostasis. A more detailed biochemical analysis has demonstrated a strong genotype-phenotype correlation, in the sense that mutations located in conserved protein coding motifs produce more severe pathology than mutations elsewhere..$^{3-5}$

With respect to internal and embryonic epithelia, studies of keratin gene knockout mice so far have underlined an essential function of these proteins in extraembryonic tissues, ${ }^{6-8}$ but have failed to support a vital role in adult internal epithelia. ${ }^{4}$ Expression of a mutated human K18 gene in transgenic mice, on the other hand, has revealed fragile hepatocytes and supports a hepatoprotective role for this keratin. ${ }^{11}$ There is evidence that such a function includes modulation of apoptotic pathways by interaction of keratins with effectors of TNF and Fas pathways. ${ }^{91-24}$ Mutant K8 has so far not been tested in transgenic mice. Collectively, these and additional data ${ }^{4}$ support the hypothesis that K8 and K18 have a non-structural function in digestive epithelia and that corresponding mutations might predispose individuals to liver or gastrointestinal disease. In fact, several reports have now identified mutations in either $\mathrm{K} 8$ or $\mathrm{K} 18$ genes as risk factors for liver disease of multiple aetiologies. ${ }^{10}$ Of these

\section{Key points}

- Mutations in $\mathrm{K} 8$ and $\mathrm{K} 18$ genes may constitute risk factors for liver disease of multiple aetiologies.

- Other data support a hepatoprotective role for human $\mathrm{K} 18$ in transgenic mice, but K8 has not so far been tested similarly.

- The present mutation analysis showed none of these mutations in 256 patients with liver disorder, but did show a novel polymorphism in the K8 gene.

- Further work with animal models and European liver patients is needed.

mutations, six of each were found in K8 and K18 genes, respectively, in non-conserved locations with regard to those observed in epidermal keratin genes. All of these represent heterozygous single base exchanges. The total frequency of $\mathrm{K} 8$ and K18 mutations amounted to 0.036 , compared with 0.0057 in control groups.

In order to assess the role of K8 and K18 mutations as potential risk factors for patients with various chronic liver disorders in the European Caucasian population, samples from more than 250 subjects suffering from a range of liver disorders, and from a control group of 100 unaffected individuals, were analysed and compared.

\section{MATERIALS AND METHODS}

\section{Patients}

Genomic DNA from peripheral leucocytes or liver biopsies was prepared using standard procedures. Of the 256 patients recruited for this study, 21 were infected with hepatitis $B$ virus (HBV); 126 with hepatitis $C$ virus; 11 had non-alcoholic steatohepatitis; 32 had primary biliary cirrhosis; 18 had primary sclerosing cholangitis; 22 had autoimmune hepatitis; five were in fulminant hepatitic failure; 10 were suffering from cryptogenic cirrhosis; and 11 had liver disorder of unknown aetiology. These patients were chosen because alterations in the keratin cytoskeleton, such as reorganization and formation of aggregates, have been described in these disorders, ${ }^{20}$ and because certain viral proteases cleave keratins 8 and $18 .{ }^{18}{ }^{19}$ As a reference group, 100 white blood donors from the Bonn University transfusion centre were selected randomly.

\section{PCR amplification}

PCR was performed using IU Platinum Taq (Invitrogen, Karlsruhe, Germany), $200 \mu \mathrm{m}$ dNTPs, $1.5-2.0 \mathrm{mM} \mathrm{MgCl}_{2}$ (see table), 5\% DMSO, and $0.5 \mu \mathrm{M}$ of the corresponding primer (table 1), in a total volume of $25 \mu \mathrm{l}$. Conditions were 
as follows: five minutes at $94^{\circ} \mathrm{C},\left(25\right.$ seconds at $94^{\circ} \mathrm{C}$, 25 seconds at $61.3-65.6^{\circ} \mathrm{C}$ (see table), and one minute at $\left.72^{\circ} \mathrm{C}\right) \times 35$ cycles. Of the reaction, $10 \mu \mathrm{l}$ was checked for the expected product on an agarose gel. PCR products from genomic DNA of one blood donor were fully sequenced and used as controls. Equal amounts of control product were mixed with the patient samples, denatured for 10 minutes at $94^{\circ} \mathrm{C}$, and allowed to cool slowly to room temperature for heteroduplex formation.

\section{DHPLC analysis and sequencing}

Mixed amplicons were analysed by DHPLC using the Transgenomic WAVE system (Transgenomic, Omaha, Neb., USA). For validation, positive control samples with the p.Y54H and p.G62C variations in $\mathrm{K} 8$ and the p.R90C variation in K18 were used (gift from B Omary). These variations could be detected, using exactly the same conditions as for the screening protocol: $5 \mu \mathrm{l}$ of the mixed amplicons were loaded on a DNAsep column and eluted on a linear acetonitril gradient in a $0.1 \mathrm{M}$ triethylamine acetate buffer $(\mathrm{pH} 7)$ with a constant flow rate of $1.5 \mathrm{ml} /$ minute. All samples were injected at different temperatures, to minimise the risk of missing mutations (table 1). The optimal melt temperature for detection of the A-G polymorphism in K8 exon 4 was $60^{\circ} \mathrm{C}$; for the $\mathrm{C}>\mathrm{G}$ polymorphism in $\mathrm{K} 18$, Intron $\mathrm{l}$, it was $60.7^{\circ} \mathrm{C}$. Sequencing was performed by automated fluorescent dideoxy sequencing (AGOWA, Berlin, Germany).

\section{RT-PCR}

Total RNA from a biopsy of the transplanted liver of a patient carrying the g.418-4C $>\mathrm{G}$ variation, and from a control, was isolated using TRIzol Reagent (Gibco-BRL, Gaithersburg, MD, USA). For the RT-reaction, the Expand Reverse Transcriptase (Roche; Mannheim, Germany) was used. PCR reaction was performed with the primer 5'-GCAAAGCCTGAGTCCTGTCC3', specific for the $5^{\prime}$-end, and $5^{\prime}$-TTTATTGGCCTCCTGCTC CCC- $3^{\prime}$, specific for the $3^{\prime}$-end of the K18 cDNA. Conditions were as follows: $94^{\circ} \mathrm{C}$ for two minutes, $\left(94^{\circ} \mathrm{C}\right.$ for 25 seconds, $65^{\circ} \mathrm{C}$ for 25 seconds, and $72^{\circ} \mathrm{C}$ for one minute) $\times 35$ cycles, and $72^{\circ} \mathrm{C}$ for 10 minutes, with Taq polymerase (MBI Fermentas, Walldorf, DC, USA).

\section{RESULTS}

Genomic DNA from peripheral blood samples was used for PCR amplification with primers specific for all exons of K8 and K18. After analysis of fragments on a DHPLC high throughput system, all detected mutations were identified by sequencing. In none of 256 patients suffering from a variety of liver diseases could mutations altering amino acids be detected. However, a g.740A $>$ G sequence variation p.L227L was found very frequently in all patients (fig 1A, B). Of the 256 patients, 54\% were heterozygous, $26 \%$ homozygous at this CTG, and 20\% homozygous for CTA. This polymorphism was observed in the analysed controls as well: $46 \%$ were heterozygous, $24 \%$ homozygous at this CTG, and $30 \%$ homozygous for CTA. Another polymorphism in the K18 gene was detectable in one patient suffering from HBV at the end of intron 1 (fig $1 C, D$ ). This g.418-4C $>$ G variation could possibly affect the nearby splicing site and lead to an alternative spliced product. To test this, RT-PCR with primers specific for the 5' - and 3'-end of the human K18 cDNA was performed on total liver RNA. Only one product with the expected size of $1.3 \mathrm{~kb}$ was obtained from the RNA of the patient carrying the g.418-4C $>\mathrm{G}$ variation as well as from the control RNA (fig 2). This clearly demonstrates that the g.418$4 \mathrm{C}>\mathrm{G}$ variation does not affect the splicing of the K18 cDNA.

\section{DISCUSSION}

Data from transgenic mice have suggested a correlation between mutations in keratin 8 and 18 and liver diseases in humans. ${ }^{11}$ These mice carried a point mutation in keratin 18 , in analogy to a hot spot mutation in epidermolysis bullosa simplex, and as a consequence suffered from chronic hepatitis. The mutations found in patients with cryptogenic

Table 1 Primer sequences, PCR conditions, temperatures, and temperature gradients used for DHPLC mutation screening of genes $\mathrm{K} 8$ and $\mathrm{K} 18$

\begin{tabular}{|c|c|c|c|c|c|}
\hline Exon & Sequence & $\mathrm{MgCl}_{2}$ & Anealing temp & Product size & Temp gradient \\
\hline K8 Exl 5' & 5'-AGAAGCAGCTTCTCCGCTC-3' & & & & \\
\hline K8 Exl 3' & 5'-GGACTACCAGGAGAAAGGGG-3' & $2.0 \mathrm{mM}$ & $64.1^{\circ} \mathrm{C}$ & 452 & $62.5-65.5^{\circ} \mathrm{C}$ \\
\hline K8 Ex2 5 & 5'- AAAAGACTGCTTGCTTTCCTC -3' & & & & \\
\hline K8 Ex2 3' & 5'- AGGTGACTTCAGTTGGGTGG -3' & $1.5 \mathrm{mM}$ & $64.1^{\circ} \mathrm{C}$ & 322 & $60.0-62.0^{\circ} \mathrm{C}$ \\
\hline $\mathrm{K} 8 \mathrm{Ex} 35^{\prime}$ & 5'- AGGGCAACCTCCCTITTG -3' & & & & \\
\hline K8 Ex3 $3^{\prime}$ & 5'- CAGTGTCCAGATAGGAGAAGGG -3' & $2.0 \mathrm{mM}$ & $64.1^{\circ} \mathrm{C}$ & 148 & $59.5+60.5^{\circ} \mathrm{C}$ \\
\hline K8 Ex4 5 & 5'- GGCTCCCCTCTCCTCATC - $3^{\prime}$ & & & & \\
\hline K8 Ex4 3' & 5' - TCTCCTGCGACCAGGAAC -3' & $2.0 \mathrm{mM}$ & $62.7^{\circ} \mathrm{C}$ & 142 & $60.0+61.0^{\circ} \mathrm{C}$ \\
\hline K8 Ex5 5 & 5'- ACCACTTGCCCTCTTCCC - $3^{\prime}$ & & & & \\
\hline K8 Ex5 3' & 5'- AGCTGAACTGTGGCTGCC -3' & $1.5 \mathrm{mM}$ & $65.6^{\circ} \mathrm{C}$ & 458 & $60.0-62.0^{\circ} \mathrm{C}$ \\
\hline K8 Ex6 5' & 5'- GAAGAGAAGGCATACCCAACC -3' & & & & \\
\hline K8 Ex6 3' & 5'- ACAGGACCCCAAGTCCAAG -3' & $1.5 \mathrm{mM}$ & $65.6^{\circ} \mathrm{C}$ & 373 & $63.5-65.5^{\circ} \mathrm{C}$ \\
\hline $\mathrm{K} 8 \mathrm{Ex} 75^{\prime}$ & 5'- GAAGGGCTAGGAGTGGTCC -3' & & & & \\
\hline K8 Ex7 3' & 5'- TGAGCGACTGAGCACAGC - $3^{\prime}$ & $1.5 \mathrm{mM}$ & $65.6^{\circ} \mathrm{C}$ & 188 & $61.0-66.0^{\circ} \mathrm{C}$ \\
\hline K8 Ex8 5 & 5'- TGTGGCTACCTCTGTCCCTC - $3^{\prime}$ & & & & \\
\hline K8 Ex8 3' & 5'- GAGGGGTAGGCTGGGAGG -3' & $1.5 \mathrm{mM}$ & $62.7^{\circ} \mathrm{C}$ & 246 & $64.0-66.0^{\circ} \mathrm{C}$ \\
\hline K18 Exl 5' & 5'- CCTGTCCTTTCTCTCTCCCC - $3^{\prime}$ & & & & \\
\hline K18 Exl 3' & 5'- TCCCTCCTACCCCTTACCTG -3' & $1.5 \mathrm{mM}$ & $61.3^{\circ} \mathrm{C}$ & 461 & $62.0-67.0^{\circ} \mathrm{C}$ \\
\hline $\mathrm{K} 18 \mathrm{Ex} 25^{\prime}$ & 5'- TGGGACCAGGAAGTITCAC -3' & & & & \\
\hline K18 Ex2 3' & 5'- GTCCTTCTTAGCTCCACCCC - $3^{\prime}$ & $1.5 \mathrm{mM}$ & $62.7^{\circ} \mathrm{C}$ & 241 & $60.0+61.0^{\circ} \mathrm{C}$ \\
\hline K18 Ex3 5' & 5'- TGGATCAGAGATAGGGGCC - $3^{\prime}$ & & & & \\
\hline K18 Ex3 3' & $5^{\prime}-$ TTCTCTTGGCCCCTCAATC - $3^{\prime}$ & $1.5 \mathrm{mM}$ & $62.7^{\circ} \mathrm{C}$ & 248 & $62.0+63.0^{\circ} \mathrm{C}$ \\
\hline K18 Ex4 5' & 5'- AGAGGCAATCACAGAAGAAAGG -3' & & & & \\
\hline K18 Ex4 3' & 5'- CACACCTTGGCAGCCATC - $3^{\prime}$ & $1.5 \mathrm{mM}$ & $62.7^{\circ} \mathrm{C}$ & 276 & $60.5-63.5^{\circ} \mathrm{C}$ \\
\hline K18 Ex5 5 & 5'- TCTCAGCAGGTGCGTGAG - $3^{\prime}$ & & & & \\
\hline K18 Ex5 3' & 5'- GGGCAGGTGATGTGAAGG -3' & $1.5 \mathrm{mM}$ & $62.7^{\circ} \mathrm{C}$ & 245 & $61.5-63.5^{\circ} \mathrm{C}$ \\
\hline K18 Ex6 5 & 5' - GATGAGCAGTCCTGGGACTC -3' & & & & \\
\hline K18 Ex6 3' & 5'- CAGTGAACAGACACATGGGG -3' & $1.5 \mathrm{mM}$ & $62.7^{\circ} \mathrm{C}$ & 377 & $62.0-64.0^{\circ} \mathrm{C}$ \\
\hline K18 Ex7 5 & 5' - GCTGITIATAACTTGGGCTTGG -3' & & & & \\
\hline K18 Ex7 3' & 5' - TCCTGCTCCCAAAGGGTAC -3' & $1.5 \mathrm{mM}$ & $62.7^{\circ} \mathrm{C}$ & 190 & $61.0+62.0^{\circ} \mathrm{C}$ \\
\hline
\end{tabular}



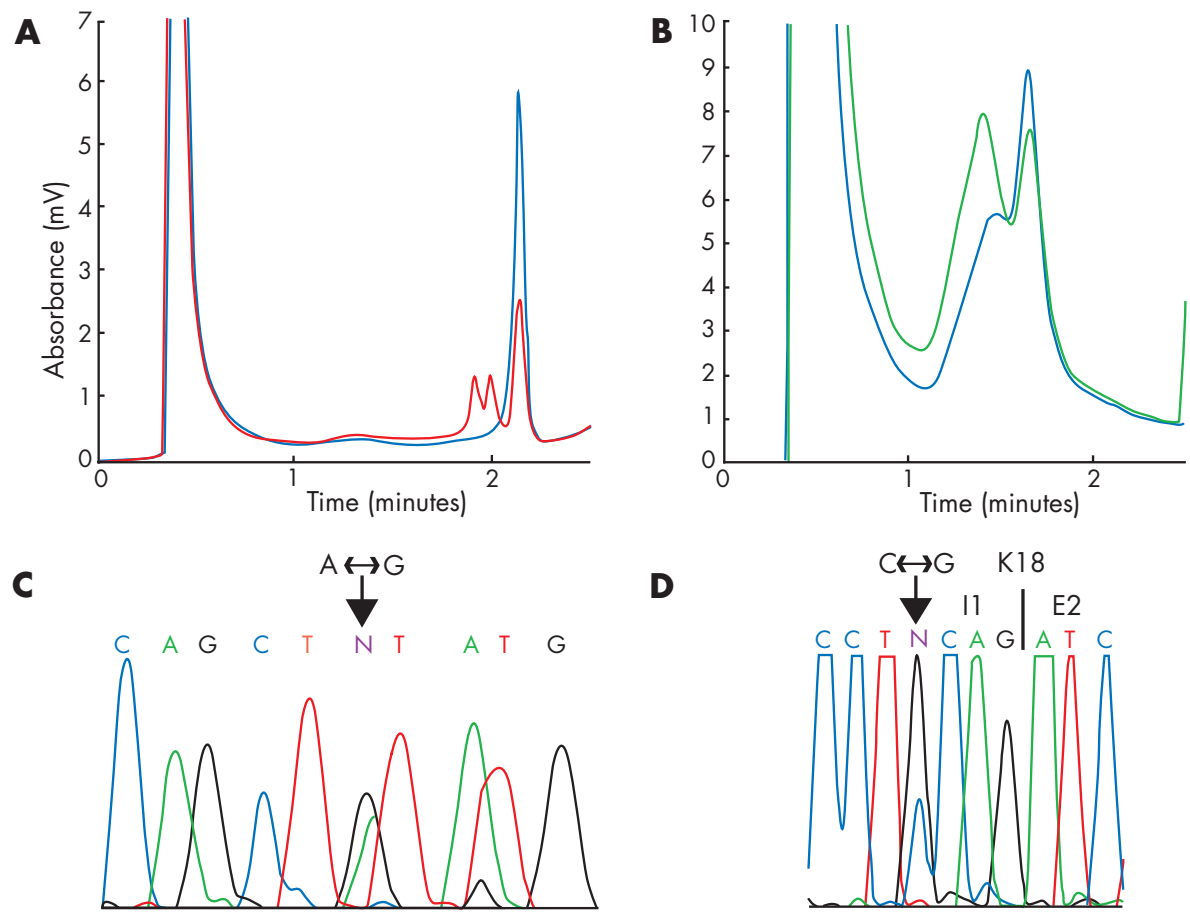

Figure 1 (A) Detection of a heterozygous g.740A $>$ G p.L227L polymorphism by DHPLC (blue wild type, red polymorphism). (B) Automated fluorescent dideoxy sequencing. (C) Detection of a variation of g.418-4C>G in the sequence of intron 1 (II) adjacent to exon 2 (E2) in a patient suffering from HBV by DHPLC (blue wild type, green mutation). (D) Automated fluorescent dideoxy sequencing. The elution time is on the $x$ axis; the ultraviolet absorbance at $260 \mathrm{~nm}(\mathrm{mV})$ is on the $y$ axis.

cirrhosis were predominantly and most frequently p.Y54H and p.G62C in the head domain of K8. ${ }^{10} 12$ Cells transiently transfected with keratin 8 carrying those mutations showed a normal keratin cytoskeleton under standard culture conditions, but displayed alterations in the filaments after applying pharmacological stress, including okadaic acid, hydrogen peroxide, or heat. ${ }^{13}$

However, there is no evidence yet from mouse models that the p.Y54H and p.G62C-mutations in K18 predispose to liver disease or cause an increased susceptibility to stress factors. Mutations used so far for liver studies in transgenic mice were p.R90C, ${ }^{11}$ p.S34A, ${ }^{14}$ p.S53A ${ }^{15}$ in K18, K8 ${ }^{\text {null }}{ }^{16}$ and $\mathrm{K} 18^{\text {null }}{ }^{17}$ Such mutations have not been detected in humans so far. It would be useful to develop mouse models carrying p.Y54H- and p.G62C-mutations in $\mathrm{K} 8$ in order to investigate conditions under which these mutations affect disease progression.

The contrary result of our study to the mutations reported so far suggests that allele frequencies might possibly differ between European and North American populations. It might be also possible that additional risk factors coincide with K8 and K18 mutations in Northern American but not European liver patients. The question arises as to whether patients suffering from liver diseases are the most likely disease group

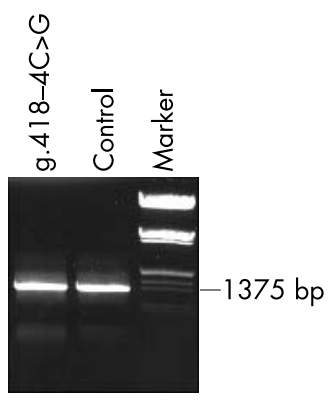

Figure 2 RT-PCR of RNA from a patient carrying the g.418-4C>G variation and a control. In both reactions a band with a size of $1.3 \mathrm{~kb}$ was obtained, indicating no splicing variants. to carry mutations in $\mathrm{K} 8$ and $\mathrm{K} 18$. Evidence from animal models strongly suggests an essential role for K8, 18, and 19 during embryonic development. Mice deficient for K8 in the C57BL/6 strain and with a compound deficiency for K18/19 and $\mathrm{K} 8 / 19$ display embryonic lethality during mid gestation..$^{6-8}$ It seems likely that mutations in analogy to hot spot mutations in human skin fragility syndromes at the ends of the rod domain are able to cause early embryonic lethality in humans.

\section{Authors' affiliations}

M Hesse, T M Magin, Institut für Physiologische Chemie, Abteilung wuer Zellbiochemie, Universitätsklinikum Bonn, Germany

R P Woitas, U Spengler, Klinik fur Innere Medizin I, Rheinische Friedrich Wilhelms Universität Bonn, Germany

T Berg, B Wiedenmann, Medizinische Klinik mit Schwerpunkt Hepatologie und Gastroenterologie, Medizinische Fakultät der Humboldt-Universität zu Berlin, Germany

Correspondence to: Prof. T M Magin, Institut für Physiologische Chemie, Abteilung fuer Zellbiochemie, Bonner Forum Biomedizin and LIMES, Universitätsklinikum Bonn, Nussallee 11, 53115 Bonn, Germany; t.magin@uni-bonn.de

\section{REFERENCES}

1 Hesse M, Magin TM, Weber K. Genes for intermediate filament proteins and the draft sequence of the human genome: novel keratin genes and a surprisingly high number of pseudogenes related to keratin genes 8 and 18 . J Cell Sci 2001;114:2569-75

2 Irvine AD, McLean WH. Human keratin diseases: the increasing spectrum of disease and subtlety of the phenotype-genotype correlation. $\mathrm{Br} J$ Dermatol $1999 ; 140(5): 815-28$

3 Fuchs $E$, Cleveland DW. A structural scaffolding of intermediate filaments in health and disease. Science 1998;279(5350):514-19.

4 Coulombe PA, Omary MB. 'Hard' and 'soft' principles defining the structure, function and regulation of keratin intermediate filaments. Curr Opin Cell Biol 2002; 14(1):110-22.

5 Herrmann H, Hesse M, Reichenzeller M, Aebi U, Magin TM. Functional complexity of intermediate filament cytoskeletons: from structure to assembly to gene ablation. Int Rev Cytol 2003;223:83-175. 
6 Hesse M, Franz T, Tamai Y, Taketo MM, Magin TM. Targeted deletion of keratins 18 and 19 leads to trophoblast fragility and early embryonic lethality. EMBO J 2000;19(19):5060-70.

7 Tamai Y, Ishikawa T, Bosl MR, Mori M, Nozaki M, Baribault H, Oshima RG, Taketo MM. Cytokeratins 8 and 19 in the mouse placental development. J Cell Biol 2000;151(3):563-72.

8 Jaquemar D, Kupriyanov S, Wankell M, Avis J, Benirschke K, Baribault H, Oshima RG. Keratin 8 protection of placental barrier function. J Cell Biol 2003;161(4):749-56

9 Oshima RG. Apoptosis and keratin intermediate filaments. Cell Death Differ 2002;9(5):486-92.

10 Ku NO, Darling JM, Krams SM, Esquivel CO, Keeffe EB, Sibley RK, Lee YM, Wright TL, Omary MB. Keratin 8 and 18 mutations are risk factors for developing liver disease of multiple etiologies. Proc Natl Acad Sci U S A 2003; 100(10):6063-8.

11 Ku NO, Michie S, Oshima RG, Omary MB. Chronic hepatitis, hepatocyte fragility, and increased soluble phosphoglycokeratins in transgenic mice expressing a keratin 18 conserved arginine mutant. J Cell Bio 1995;131(5):1303-14.

12 Ku NO, Wright TL, Terrault NA, Gish R, Omary MB. Mutation of human keratin 18 in association with cryptogenic cirrhosis. J Clin Invest 1997:99(1):19-23

13 Ku NO, Gish R, Wright TL, Omary MB. Keratin 8 mutations in patients with cryptogenic liver disease. N Engl J Med 2001;344(21):1580-7.

14 Ku NO, Michie S, Resurreccion EZ, Broome RL, Omary MB. Keratin binding to 14-3-3 proteins modulates keratin filaments and hepatocyte mitotic progression. Proc Natl Acad Sci U S A 2002:99(7):4373-8.

15 Ku NO, Michie SA, Soetikno RM, Resurreccion EZ, Broome RL, Omary MB. Mutation of a major keratin phosphorylation site predisposes to hepatotoxic injury in transgenic mice. J Cell Biol 1998;143(7):2023-32.
16 Zatloukal K, Stumptner C, Lehner M, Denk H, Baribault H, Eshkind LG, Franke WW. Cytokeratin 8 protects from hepatotoxicity, and its ratio to cytokeratin 18 determines the ability of hepatocytes to form Mallory bodies. Am J Pathol 2000;156(4):1263-74.

17 Magin TM, Schroder R, Leitgeb S, Wanninger F, Zatloukal K, Grund C, Melton DW. Lessons from keratin 18 knockout mice: formation of novel keratin filaments, secondary loss of keratin 7 and accumulation of liver-specific keratin 8-positive aggregates. J Cell Biol 1998;140(6):1441-51.

18 Seipelt J, Liebig HD, Sommergruber W, Gerner C, Kuechler E. 2A proteinase of human rhinovirus cleaves cytokeratin 8 in infected HeLa cells. J Biol Chem 2000;275(26):20084-9.

19 Chen PH, Ornelles DA, Shenk T. The adenovirus L3 23-kilodalton proteinase cleaves the amino-terminal head domain from cytokeratin 18 and disrupts the cytokeratin network of HeLa cells. J Virol 1993;67(6):3507-14.

20 Denk H, Stumptner C, Zatloukal K. Mallory bodies revisited. J Hepatol 2000;32(4):689-702.

21 Ku NO, Soetikno RM, Omary MB. Keratin mutation in transgenic mice predisposes to Fas but not TNF-induced apoptosis and massive liver injury. Hepatology 2003;37(5):1006-14.

22 Inada H, Izawa I, Nishizawa M, Fujita E, Kiyono T, Takahashi T, Momoi T, Inagaki $M$. Keratin attenuates tumor necrosis factor-induced cytotoxicity through association with TRADD. J Cell Biol 2001;155(3):415-26.

23 Gilbert S, Loranger A, Daigle N, Marceau N. Simple epithelium keratins 8 and 18 provide resistance to Fas-mediated apoptosis. The protection occurs through a receptor-targeting modulation. J Cell Biol $2001 ; 154(4): 763-73$

24 Caulin C, Ware CF, Magin TM, Oshima RG. Keratin-dependent, epithelial resistance to tumor necrosis factor-induced apoptosis. J Cell Biol 2000; 149(1):17-22. 